\title{
FARMS FROM AREAS OF HIGH NATURE VALUE (HNV) AGAINST THE BACKGROUND OF OTHER FARMS
}

\author{
MAREK ZIELIŃSKI \\ JOLANTA SOBIERAJEWSKA
}

\begin{abstract}
The study shows a comparative analysis of areas (communes) with a varying level of saturation with high nature value utilised agricultural area (HNV $U A A)$ and assessed the functioning of farms from these areas in Poland. Firstly, three groups of communes differing in terms of the share of HNVUAA in the total area were identified. The first group were communes with the share of HNV $U A A$ in the total area amounting to less than 10\% (1st group communes), the second - communes with the share of HNV UAA equal to or higher than $10 \%$ and lower than 40\% (2nd group communes), and the third-communes with the share of HNV UAA of at least 40\% (3rd group communes). In these communes, the assessment covered the average number of farms along with their average $U A A$, percentage (\%) of communes with farms having the average UAA equal to or higher than the Polish average, as well as the change in $\%$ in the population and the share in \% in the communes where the population decreased by at least 5\% in 2004-2017 and their average agricultural production area valorisation index (APAV). Then, the assessment of functioning covered 2878 farms with crop, livestock and mixed (crop and livestock) production from those communes which have continuously kept accounts for the Polish FADN system in 2014-2016. This assessment took account of their production potential, production organisation, land and labour productivity and income per 1 FWU. The study used the data from the Agency for Restructuring and Modernisation of Agricul-
\end{abstract}

\footnotetext{
Dr inż. Marek Zieliński, Institute of Agricultural and Food Economics - National Research Institute, Department of Economics of Agricultural and Horticultural Holdings; ul. Świętokrzyska 20, 00-002 Warsaw (marek.zielinski@ierigz.waw.pl); ORCID iD: 0000-0002-6686-5539.

Mgr Jolanta Sobierajewska, Institute of Agricultural and Food Economics - National Research Institute, Department of Economics of Agricultural and Horticultural Holdings; ul. Świętokrzyska 20, 00-002 Warsaw (sobierajewska@ierigz.waw.pl); ORCID iD: 0000-0002-5161-696X.
} 
ture (ARiMR), the Institute of Soil Science and Plant Cultivation State Research Institute (IUNG-PIB), data from farms keeping accounts for the Polish FADN in 2014-2016 as well as literature data.

Keywords: High Nature Value utilised agricultural areas (HNV UAA), landscape, biodiversity, farm, income per $1 \mathrm{FWU}$.

JEL codes: Q15, Q57, Q59.

\section{Introduction}

According to the European Commission (EC), the European Union Common Agricultural Policy (EU CAP) post-2020, will strengthen the contribution of the agricultural sector to the conservation of landscape and biodiversity in rural areas (EC, 2017). In this context, the role of the agricultural sector in the conservation of landscape and biodiversity of high nature value rural areas becomes essential. The more that adverse changes in these areas are progressive. It is estimated that in the European Union (EU) the state of $39 \%$ of valuable natural habitats is still deteriorating, and the number of farmland birds and the wild bee population are still decreasing (EC, 2014b; 2015; OECD data $)^{1}$.

In the EU, the conservation of the landscape and biodiversity of rural areas should be served, in particular, by farms in particularly high nature value agricultural utilised area, i.e. (HNV UAA) ${ }^{2}$. In this context, it must be stressed that the EC in all EU Member States has identified the need to designate and monitor HNV UAA for the purpose of assessing the effects of the measures implemented under the RDP 2014-2020 (EC, 2014a; 2016; 2017).

In 2018, the Institute of Agricultural and Food Economics - National Research Institute (IERiGŻ-PIB), the Institute of Soil Science and Plant Cultivation - State Research Institute (IUNG-PIB), the Institute for Agricultural and Forest Environment of the Polish Academy of Sciences (IŚRiL-PAN), the Institute of Technology and Life Sciences (ITP) and the Polish Society for the Protection of Birds (OTOP), upon request of the Ministry of Agriculture and Rural Development (MRiRW) and the European Commission, put forward three proposals for the potential HNV UAA in Poland (Matyka i in., 2019; Zieliński i in., 2017). It was determined that these areas should be characterised by a high saturation of farms with extensive production organisation and operating in the surroundings of high nature value areas, i.e. permanent grassland, forests, inland waters and other areas not subjected to anthropopressure. This study analysed only the proposal (one of three) covering the largest area of potential HNV UAA in Poland.

Taking into account the EC findings on the need to strengthen, in the EU financial perspective after 2020, the role of the agricultural sector in the conservation of landscape and biodiversity of rural areas and the diversified distribution of areas with

\footnotetext{
${ }^{1}$ In the EU, about 189 species of wild bees are threatened with extinction (EC, 2014).

${ }^{2}$ In the EU, the term HNV has been used since 1993 with respect to the agricultural production systems conducive to the conservation of landscape and biodiversity of rural areas (Baldock et al., 1993).
} 
the varied landscape and conducive to the conservation of biodiversity in regional terms of Poland, it is, therefore, appropriate to carry out a comparative analysis of areas (communes) with a varying level of saturation with HNV UAA and to assess the functioning of farms from these areas.

\section{Method}

In order to achieve the objective of the analysis, the structure of the study is organised in two resulting subchapters. The first subchapter described the communes with the different share of HNV UAA in the total area in Poland based on the data from the Agency for Restructuring and Modernisation of Agriculture (ARiMR), Statistics Poland (GUS) and IUNG-PIB. To this end, the analysis used the selected data from $24781^{\text {st }}$ group communes in Poland, including 1363 communes where the share of HNV UAA in the total area was lower than $10 \%\left(1^{\text {st }} \text { group communes }\right)^{3}$, 768 communes with the share of HNV UAA equal to or higher than $10 \%$ and lower than $40 \%$ ( $2^{\text {nd }}$ group communes) and 347 communes with the share of HNV UAA of at least $40 \%$ ( $^{\text {rd }}$ group communes $)^{4}$.

The comparative analysis of the $1^{\text {st }}, 2^{\text {nd }}$ and $3^{\text {rd }}$ group communes took account of:

- The average number of farms and their average UAA, as well as the percentage $(\%)$ of communes with farms that have the average UAA equal to or higher than the Polish average ${ }^{5}$,

- The change in $\%$ in the population and share in $\%$ of the communes where the population decreased by at least $5 \%$ in $2004-2017$,

- The average agricultural production area valorisation index (APAV)

On the other hand, the second subchapter contained the comparative assessment of 2878 farms from the $1^{\text {st }}, 2^{\text {nd }}$ and $3^{\text {rd }}$ group communes, which have continuously kept accounts for the Polish FADN in 2014-2016. Among the farms from the $1^{\text {st }}$ group communes, the following were separated: 744 farms with crop production, 447 with mixed (crop and livestock) production and 171 with livestock production. In contrast, among the farms from the $2^{\text {nd }}$ group communes, there were, respectively, 412 farms with crop production, 301 with mixed production and 431 with livestock production, and in the case of the $3^{\text {rd }}$ group communes -106 farms with crop production, 101 farms with mixed production and 165 with livestock production.

The identified groups of farms did not include the farms with intensive production organisation whose impact on the conservation of landscape and biodiversity of rural areas is often negative and the impact of high nature value areas on their production

\footnotetext{
${ }^{3}$ The $1{ }^{\text {st }}$ group also includes the communes without HNV UAA.

${ }^{4}$ In Poland, there are 2478 communes as of January 1, 2016.

${ }^{5}$ In Poland, the average area of the farm in 2016 amounted to 10.3 ha of UAA (GUS, 2017).

${ }^{6}$ The APAV index includes factors affecting the quality of natural farming conditions such as: soil quality, hydrographic conditions, land relief and agroclimate. Each of them has been attributed the weight proportional to its impact on the crop yield (GUS, 2013).
} 
and economic effects is usually small ${ }^{7}$. In this type of farms, livestock production is often conducted with a large share of purchased feed, while crop production (horticultural and permanent crops) is often conducted under covers and irrigated.

The comparative analysis of the farms took account of their:

1) production potential:

- UAA expressed in ha and consisting of: own land, land leased for one year or more, land used based on harvest sharing with the owner, as well as fallow and set-aside land,

- total labour inputs per 1 ha of UAA, covering total human labour inputs as part of the operating activities of the farm, expressed in hours,

- value of capital (PLN thousand);

2) production organisation:

- share of arable land (AL) in utilised agricultural area (\%),

- share of permanent grassland (PG) in utilised agricultural area (\%),

- stocking density in livestock units per 1 ha of UAA (LU/ha of UAA);

3) productivity and economic situation:

- land productivity specified as a ratio of total production value on the farm to utilised agricultural area (PLN thousand/ha of UAA),

- labour productivity specified as a ratio of total production value to the number of fully employed persons (AWU) (PLN thousand/AWU),

- farm income per own work unit of the farm manager and his family members in Family Work Unit (FWU) (PLN thousand/FWU).

\section{Characteristics of the communes with different share of HNV UAA in the total area in Poland}

As indicated in the introduction, this study contains results only for proposal (one of three) with the largest area of potential HNV UAA in Poland. According to the findings of the IERiGŻ-PIB, IUNG-PIB, IŚRiL-PAN, ITP, OTOP from 2018, in Poland in this variant the area of potential HNV UAA is 4.1 million ha ${ }^{8}$.

In Poland, 55.0\% (1363) of the communes are in the $1^{\text {st }}$ group, $31.0 \%$ (768) in the $2^{\text {nd }}$ group and the remaining $14.0 \%(347)$ in the $3^{\text {rd }}$ group. The communes with the largest share of HNV UAA in the total area are particularly in the Lubelskie, Małopolskie, Mazowieckie, Podlaskie and Świętokrzyskie Voivodeships (Map 1). It must be added that in Poland there are 10 communes with the share of HNV UAA in the total area amounting to at least $70.0 \%$.

\footnotetext{
${ }^{7}$ Farms with intensive production organisation are those which exceeded the threshold value of at least one of three identified technical and organisational indicators (stocking density equal to or higher than $0.9 \mathrm{LU}$ per 1 ha of UAA, share of permanent crops in UAA equal to or higher than $35.7 \%$, share of horticultural crops in UAA equal to or higher than $15 \%$ ). The method of selecting farms with intensive production organisation has been described in detail in the study entitled Description and results of the fine-tuning procedure's application in Poland (IERiGŻ - PIB and MRiRW 2017) and Aktualizacja metody wyznaczania gospodarstw i obszarów o ekstensywnej produkcji rolnej w ramach HNV wraz z obszarami charakterystycznymi dla HNV (wariant II) (Zieliński, Sobierajewska and Kagan, 2017).
}

${ }^{8}$ In this variant the area of potential HNV UAA (Matyka et al., 2019). 


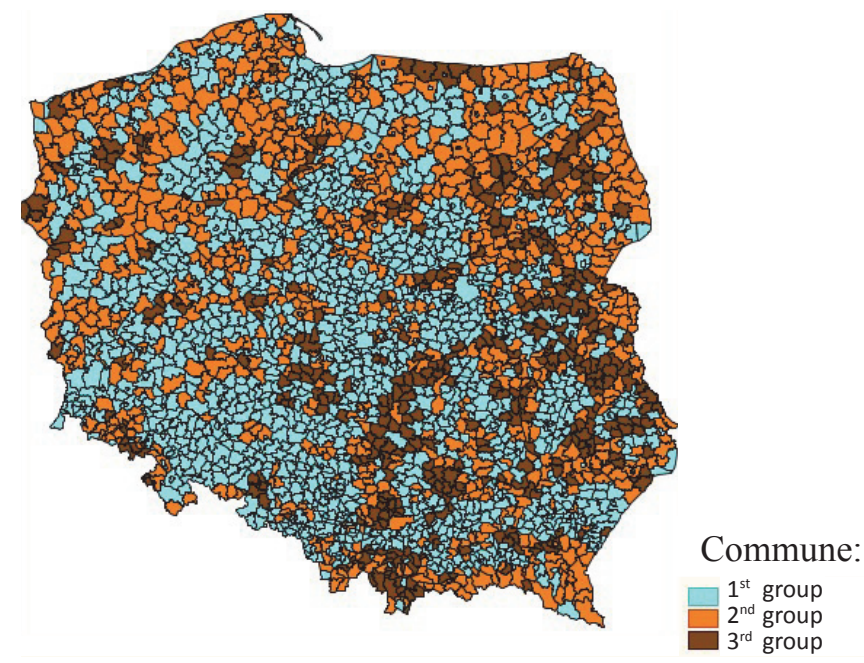

Map 1. Distribution of the $1^{\text {st }}, 2^{\text {nd }}$ and $3^{\text {rd }}$ group communes in Poland.

Source: own study based on the data from IERiGŻ-PIB, IUNG-PIB, IŚRiL-PAN, ITP, OTOP of 2018.

In Poland, at the level of communes, there are clear differences in the average number of farms and their average UAA (Map 2 and Map 3). It was found that the average number of farms increased in the communes with the increase in the share of HNV UAA in the total area. In the $1^{\text {st }}$ group communes, their number amounted to 466 , in the $2^{\text {nd }}$ group communes -525 , and in the $3^{\text {rd }}$ group communes -675 (data from ARiMR, status as of 31.12.2017).

In addition, in the $1^{\text {st }}, 2^{\text {nd }}$ and $3^{\text {rd }}$ group communes, there were differences in the average area of farms. In the $1^{\text {st }}$ and $2^{\text {nd }}$ group, the average area of farms amounted to 12 and 12.1 ha of UAA, respectively, while in the $3^{\text {rd }}$ group communes -8.5 ha of UAA. Moreover, in the $1^{\text {st }}$ and $2^{\text {nd }}$ group, the share of the communes with the average area of farms equal to or higher than the national average was $48.1 \%$ and $50.9 \%$, respectively. In the $3^{\text {rd }}$ group, the share of such communes was considerably smaller and amounted to $24.4 \%$ (Table 1 ).

Important elements differentiating the analysed communes are also the change in $\%$ in the population and the share in $\%$ of the communes where the population decreased by at least 5\% in 2004-2017. It was found that in the $1^{\text {st }}$ and $2^{\text {nd }}$ group there was an average increase in the population by $3.0 \%$ and $2.5 \%$, respectively, while the share in $\%$ of the communes where the population decreased by at least $5 \%$ in both groups of the communes was identical and amounted to $22.0 \%$. In this respect, the $3^{\text {rd }}$ group communes were in a much worse situation. In the case of these communes, the population decreased by $1.2 \%$ and the share of the communes where the population decreased by at least $5 \%$ amounted to $39.0 \%$.

Among the factors which have a strong impact on the functioning of farms from the $1^{\text {st }}, 2^{\text {nd }}$ and $3^{\text {rd }}$ group, we should mention their natural farming conditions. These conditions were described using the APAV index. In Poland, the average APAV in- 
dex is 66.8 points, although in the communes it is highly diversified (Map 4). In the case of the communes from the $1^{\text {st }}$ group, it was the largest and amounted to 70.1 points, whereas in the communes from the $2^{\text {nd }}$ and $3^{\text {rd }}$ group it was clearly smaller and amounted to 59.7 and 61.8 , respectively. In the case of the $2^{\text {nd }}$ and $3^{\text {rd }}$ group, this index was lower than the national average (Table 1).

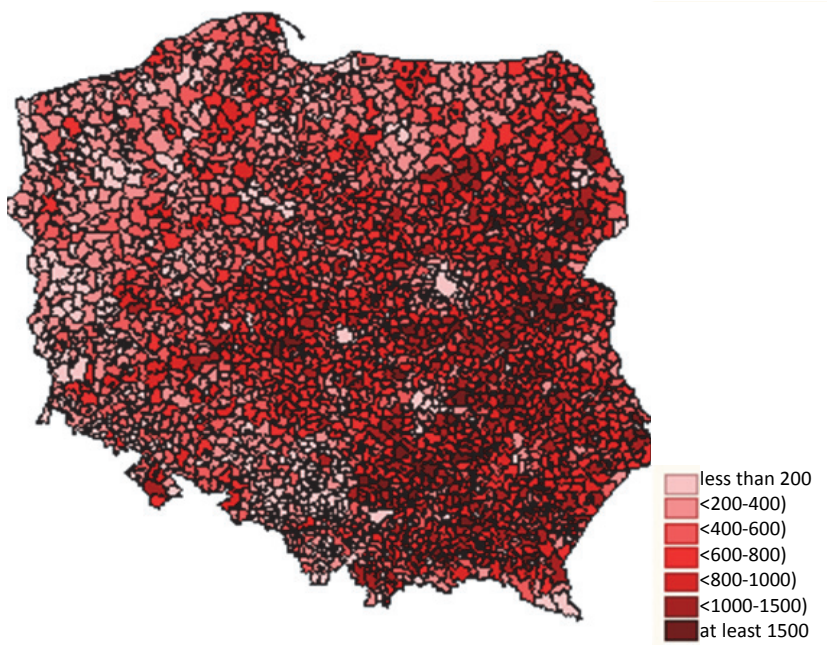

Map 2. Number of farms in the communes in Poland in 2017.

Source: own study based on the data from ARMiR, status as of 31.12.2017.

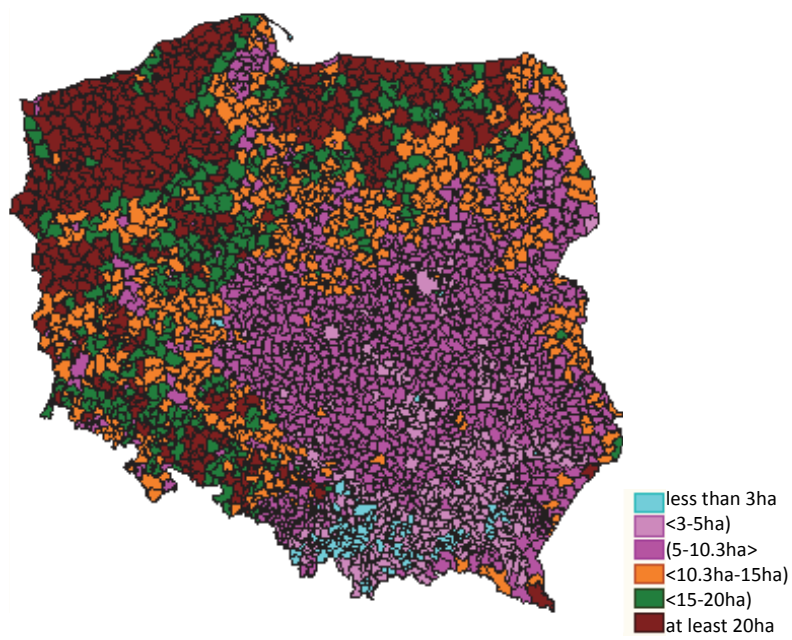

Map 3. Average UAA of farms in the communes in Poland in 2017.

Source: own study based on the data from ARMiR, status as of 31.12.2017. 


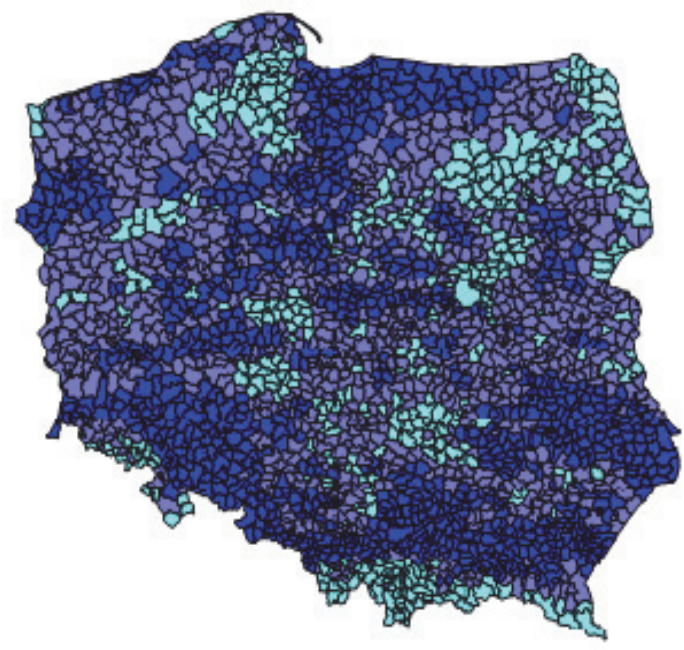

APAV index below 52 points APAV index of at least 52 and below 66 . APAV index of at least 66.8 points

Map 4. Average value of the APAV index (points) in the communes in Poland.

Source: own study based on the data from IUNG-PIB.

Selected characteristics for the $1^{\text {st }}, 2^{\text {nd }}$ and $3^{\text {rd }}$ group communes in Poland

Table 1

\begin{tabular}{lccc}
\hline \multirow{2}{*}{ Specification } & \multicolumn{3}{c}{ Communes from } \\
\cline { 2 - 4 } & $1^{\text {st }}$ group & $2^{\text {nd }}$ group & $3^{\text {rd }}$ group \\
\hline Share in \% of communes in Poland & 55.0 & 31.0 & 14.0 \\
Average number of farms per commune & 466 & 525 & 675 \\
$\begin{array}{l}\text { Average area of the farm (ha of UAA) } \\
\text { Share in \% of communes with the average area } \\
\text { of the farm equal to or higher than the national average }\end{array}$ & 12.0 & 12.1 & 8.5 \\
$\begin{array}{l}\text { Change in \% in the population in 2004-2017 } \\
\text { (2004 =100\%) }\end{array}$ & 48.1 & 50.9 & 24.4 \\
$\begin{array}{l}\text { Share of the communes where the population decreased } \\
\text { by at least 5\% in 2004-2017 (\%) }\end{array}$ & 22.0 & 22.0 & 39.0 \\
$\begin{array}{l}\text { Average agricultural production area valorisation index } \\
\text { (APAV) (points) }\end{array}$ & 70.1 & 59.7 & 61.8 \\
\hline
\end{tabular}

Source: own study based on the data from ARMiR - as of 31.12.2017, GUS and IUNG-PIB.

\section{Characteristics of the farms from the communes with the different share of HNV UAA in the total area in Poland}

As it results from the figures in Table 2, the farms from the $3^{\text {rd }}$ group when compared to the similar farms from the $1^{\text {st }}$ and $2^{\text {nd }}$ group communes had smaller UAA. On the farms with crop production, it was lower by, respectively, $29.0 \%$ and $22.1 \%$, on the farms with livestock production by $17.0 \%$ and $12.1 \%$, respectively, and on the farms with mixed production by $29.9 \%$ and $19.1 \%$, respectively. 
As regards labour inputs per 1 ha of UAA, the farms from the $3^{\text {rd }}$ group communes had the largest inputs. On the farms with crop production, they were larger than those of similar farms from the $1^{\text {st }}$ and $2^{\text {nd }}$ group communes by $40.4 \%$ and $26.7 \%$, respectively, on the farms with livestock production by $11.9 \%$ and $8.9 \%$, respectively, and on the farms with mixed production by $37.4 \%$ and $25.3 \%$, respectively. On the farms from the $3^{\text {rd }}$ group communes, irrespective of the farming type analysed, lower labour inputs per 1 ha of UAA were affected by the lower value of capital which prevented them from limiting labour inputs in the agricultural production process (Table 2).

Table 2

Production potential of the farms with crop, livestock and mixed production from the $1^{\text {st }}, 2^{\text {nd }}$ and $3^{\text {rd }}$ group communes in Poland in 2014-2016

\begin{tabular}{|c|c|c|c|}
\hline \multirow{3}{*}{ Specification } & \multicolumn{3}{|c|}{ Farms from communes from: } \\
\hline & $1^{\text {st }}$ group & $2^{\text {nd }}$ group & $3^{\text {rd }}$ group \\
\hline & \multicolumn{3}{|c|}{ Farms with crop production } \\
\hline UAA (ha) & 60.7 & 55.3 & 43.1 \\
\hline Labour input per 1 ha of UAA (hours) & 56.5 & 62.6 & 79.3 \\
\hline \multirow[t]{2}{*}{ Value of capital (PLN thousand) } & 420.3 & 386.1 & 352.1 \\
\hline & \multicolumn{3}{|c|}{ Farms with livestock production } \\
\hline UAA (ha) & 37.7 & 35.6 & 31.3 \\
\hline Labour input per 1 ha of UAA (hours) & 106.6 & 109.5 & 119.3 \\
\hline \multirow[t]{2}{*}{ Value of capital (PLN thousand) } & 308.0 & 274.9 & 258.5 \\
\hline & \multicolumn{3}{|c|}{ Farms with mixed production } \\
\hline UAA (ha) & 33.8 & 29.3 & 23.7 \\
\hline Labour input per 1 ha of UAA (hours) & 110.9 & 121.6 & 152.4 \\
\hline Value of capital (PLN thousand) & 269.8 & 239.2 & 194.0 \\
\hline
\end{tabular}

Source: own study based on the data from the Polish FADN for 2014-2016.

Production organisation on the farm may be described by a number of indicators. For the purposes of this analysis, three of them were included, namely the share of AL in UAA, share of PG in UAA and the stocking density per 1 ha of UAA. The figures in Table 3 show that on the farms with livestock and mixed production from the $3^{\text {rd }}$ group communes, when compared to the similar farms from the $1^{\text {st }}$ and $2^{\text {nd }}$ group, the share of AL in UAA was lower while the share of PG in UAA was higher. The situation was slightly different in the case of the stocking density per 1 ha of UAA. On the farms from the $2^{\text {nd }}$ and $3^{\text {rd }}$ group communes, it was identical and, at the same time, smaller than on the similar farms from the $1^{\text {st }}$ group communes. This means that the farms from the $2^{\text {nd }}$ and $3^{\text {rd }}$ group communes were characterised by less intensive organisation of livestock production. It should also be added that, in the case of the farms with crop production compared to the farms with livestock and mixed production, irrespective of their location, the share of AL in UAA was significantly higher, in turn the share of PG in UAA and the stocking density per 1 ha of UAA were of marginal importance in their case (Table 3 ). 
Table 3

Selected characteristics of production organisation on the farms with crop, livestock and mixed production from the $1^{\text {st }}, 2^{\text {nd }}$ and $3^{\text {rd }}$ group communes in Poland in 2014-2016

\begin{tabular}{|c|c|c|c|}
\hline \multirow{3}{*}{ Specification } & \multicolumn{3}{|c|}{ Farms from communes from: } \\
\hline & $1^{\text {st }}$ group & $2^{\text {nd }}$ group & $3^{\text {rd }}$ group \\
\hline & \multicolumn{3}{|c|}{ Farms with crop production } \\
\hline Share of AL in UAA (\%) & 95.9 & 93.0 & 93.5 \\
\hline Share of PG in UAA (\%) & 2.3 & 3.2 & 3.6 \\
\hline \multirow[t]{2}{*}{ Stocking density per 1 ha of UAA (LU) } & 0.05 & 0.05 & 0.05 \\
\hline & \multicolumn{3}{|c|}{ Farms with livestock production } \\
\hline Share of AL in UAA (\%) & 64.1 & 50.9 & 46.9 \\
\hline Share of PG in UAA (\%) & 35.5 & 48.3 & 52.9 \\
\hline \multirow[t]{2}{*}{ Stocking density per 1 ha of UAA (LU) } & 0.7 & 0.6 & 0.6 \\
\hline & \multicolumn{3}{|c|}{ Farms with mixed production } \\
\hline Share of AL in UAA $(\%)$ & 84.3 & 79.9 & 78.4 \\
\hline Share of PG in UAA (\%) & 14.4 & 18.6 & 21.0 \\
\hline Stocking density per 1 ha of UAA (LU) & 0.6 & 0.5 & 0.5 \\
\hline
\end{tabular}

Source: own study based on the data from the Polish FADN for 2014-2016.

The farms from the $3^{\text {rd }}$ group when compared to similar farms from the $1^{\text {st }}$ and $2^{\text {nd }}$ group communes had lower land and labour productivity. The biggest difference to their disadvantage in the land productivity occurred on farms with livestock production and amounted to $20.5 \%$ and $8.8 \%$, respectively, and in the labour productivity on the farm with mixed production, amounting to $35.6 \%$ and $21.9 \%$, respectively (Table 4 ).

Table 4

Land and labour productivity on farms with crop, livestock and mixed production from the $1^{\text {st }}, 2^{\text {nd }}$ and $3^{\text {rd }}$ group communes in Poland in 2014-2016

\begin{tabular}{|c|c|c|c|}
\hline \multirow{3}{*}{ Specification } & \multicolumn{3}{|c|}{ Farms from communes from: } \\
\hline & $1^{\text {st }}$ group & $2^{\text {nd }}$ group & $3^{\text {rd }}$ group \\
\hline & \multicolumn{3}{|c|}{ Farms with crop production } \\
\hline Land productivity (PLN thousand/ha of UAA) & 3.9 & 3.8 & 3.7 \\
\hline \multirow[t]{2}{*}{ Labour productivity (PLN thousand/AWU) } & 144.9 & 120.2 & 94.3 \\
\hline & \multicolumn{3}{|c|}{ Farms with livestock production } \\
\hline Land productivity (PLN thousand/ha of UAA) & 3.9 & 3.4 & 3.1 \\
\hline \multirow[t]{2}{*}{ Labour productivity (PLN thousand/AWU) } & 79.0 & 64.6 & 54.5 \\
\hline & \multicolumn{3}{|c|}{ Farms with mixed production } \\
\hline Land productivity (PLN thousand/ha of UAA) & 4.2 & 3.9 & 3.7 \\
\hline Labour productivity (PLN thousand/AWU) & 80.9 & 66.7 & 52.1 \\
\hline
\end{tabular}

Source: own study based on the data from the Polish FADN for 2014-2016. 
Income per $1 \mathrm{FWU}$ was used to assess the economic situation of the farms from the $1^{\text {st }}, 2^{\text {nd }}$ and $3^{\text {rd }}$ group communes. It was found that the farms from the $3^{\text {rd }}$ group communes had this income lower than similar farms from the $1^{\text {st }}$ and $2^{\text {nd }}$ group communes. On the farms with crop production, it was lower by $36.6 \%$ and $28.9 \%$, respectively, on the farms with livestock production by $21.9 \%$ and $11.6 \%$, respectively, and on the farms with mixed production by $34.2 \%$ and $30.3 \%$, respectively. It should be added that the worst situation in terms of income per 1 FWU applied to farms with mixed production from the $3^{\text {rd }}$ group, where it amounted to PLN 20 thousand. This means that on those farms that income provided labour payment for the owner and his/her family members only at the level of $63.9 \%$ of the parity payment corresponding to the annual average net remuneration in the national economy in $2014-2016^{9}$ (Fig. 1).

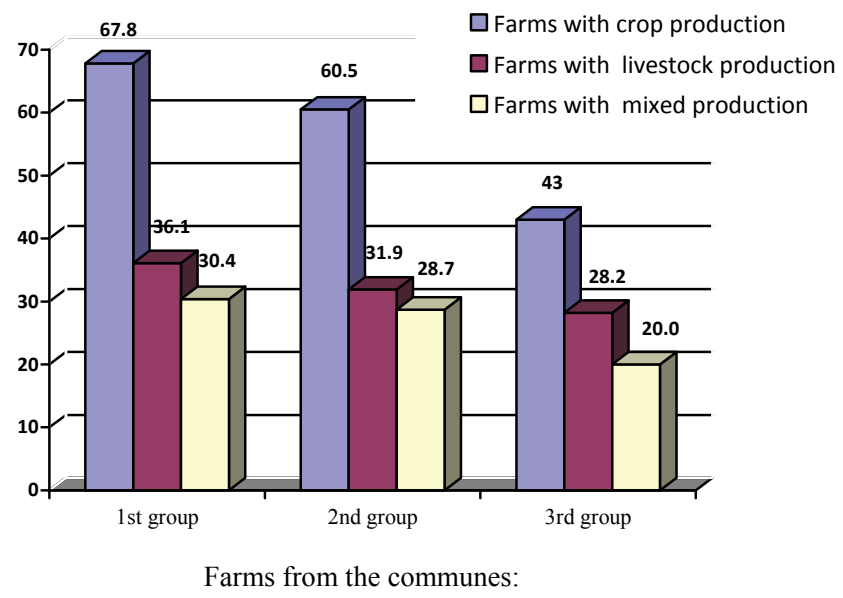

Fig. 1. Income per $1 \mathrm{FWU}$ on the farms with crop, livestock and mixed production from the $1^{\text {st }}, 2^{\text {nd }}$ and $3^{\text {rd }}$ group communes in Poland in 2014-2016.

\section{Summary and conclusions}

The study shows a comparative analysis of the communes with a varying level of saturation with HNV UAA in Poland based on the data from the ARiMR, GUS and IUNG-PIB as a comparative assessment of the farms from these communes based on the Polish FADN for 2014-2016.

In the first resulting subchapter, three groups of communes differing as regards the share of HNV UAA in the total area were identified as part of the total number of communes in Poland. The first subgroup consisted of 1363 communes with the share of HNV UAA in the total area of less than $10 \%$ ( $1^{\text {st }}$ group communes),

\footnotetext{
${ }^{9}$ In 2014-2016, the average net remuneration in the national economy was PLN 31.3 thousand (Abramczuk et al., 2016; 2017 and 2018).
} 
the second -768 communes with the share of HNV UAA equal to or higher than $10 \%$ and lower than $40 \%$, and the third - 347 communes with the share of HNV UAA of at least $40 \%$ ( $3^{\text {rd }}$ group communes). The comparative analysis took into account the average number of farms and their average UAA, the share in $\%$ of the communes with the farms having the average UAA equal to or higher than the Polish average, the change in $\%$ of the population and the share in $\%$ of the communes where the population decreased by at least 5\% in 2004-2017 and the average agricultural production area valorisation index (APAV).

In the second resulting subchapter, the comparative assessment covered 2878 farms with crop, livestock and mixed (crop-livestock) production from the $1^{\text {st }}, 2^{\text {nd }}$ and $3^{\text {rd }}$ group communes, which have continuously kept accounts for the Polish FADN in 2014-2016. This assessment took into account their production potential, production organisation, land and labour productivity and income per 1 FWU.

The following conclusions result from the findings made based on the analysis:

- Poland has great potential of HNV UAA. Area of potencial HNV UAA is 4,1 mln ha.

- The communes with the largest share of HNV UAA in the total area are located particularly in the Lubelskie, Małopolskie, Mazowieckie, Podlaskie and Świętokrzyskie Voivodeships.

- The data of ARiMR, GUS and IUNG-PIB show that the communes with the largest share of HNV UAA in the total area compared to other communes are characterised by the average higher number of farms and their lower average UAA. In addition, these communes have, on average, worse natural conditions for conducting agricultural production and are more likely to be characterised by a decrease in the population.

- It is apparent from the Polish FADN data that the farms from the communes with the largest share of HNV UAA in the total area compared to the similar farms from other communes have smaller UAA, incur more labour inputs per 1 ha of UAA and have lower value of capital. In addition, they are characterised by the lower land and labour productivity which co-determines their worse economic situation. However, it must be stressed that the data of the Polish FADN relate to the farms with the higher production potential and being economically stronger against a background of all farms in Poland. It should, therefore, be assumed that the presented economic situation of the farms does not fully reflect the situation of all farms in Poland - especially those from the communes with the largest share of HNV UAA in the total area. 


\section{References}

Abramczuk, Ł., Augustyńska, I., Bębenista, A., Żekało, M. (2018). Produkcja, koszty i dochody $z$ wybranych produktów rolniczych w latach 2016-2017. Warszawa: IERiGŻ-PIB.

Abramczuk, Ł., Augustyńska-Grzymek, I., Czułowska, M., Jabłoński, K., Żekało, M. (2015). Produkcja, koszty $i$ dochody $z$ wybranych produktów rolniczych $w$ latach 2013-2014. Warszawa: IERiGŻ-PIB.

Abramczuk, Ł., Czułowska, M., Jabłoński, K., Żekało, M. (2016). Produkcja, koszty i dochody $z$ wybranych produktów rolniczych $w$ latach 2014-2015. Warszawa: IERiGŻ-PIB.

Baldock, D., Beaufoy, G., Bennett, G., Clark, J. (1993). Nature Conservation and New Directions in the Common Agricultural Policy. London: Institute of European Environmental Policy.

Data from ARiMR database, status as of 31.12.2017 (access date: 27.11.2018).

Data from IUNG-PIB database (access date: 09.07.2018).

Description and results of the fine-tuning procedure's application in Poland (2017). Report by IERiGŻ-PIB and MRiRW for the European Commission, February.

European Commission (2014). CAP context indicators 2014-2020, 37. High Nature Value Farming. European Commission (2014). European Red List of Bees.

European Commission (2015). Report from the Commission for the European Parliament and the Council. The mid-term review of the EU biodiversity strategy to 2020. COM(2015) 478 final.

European Commission (2016). Working document. Practices to identify, monitor and assess HNV farming in RDPs 2014-2020. November 2016.

European Commission (2017). Communication from the Commission to the European Parliament, the Council, the European Economic and Social Committee and the Committee of the Regions. The Future of Food and Farming. Brussels, 29.11.2017, COM(2017) 713 final.

European Commission (2017). Working document. HNV farming indicator in RDPs 2014-2020: Overview from a survey.

European Commission (2018). Proposal for a Regulation of the European Parliament and of the Council establishing rules on support for strategic plans to be drawn up by Member States under the Common agricultural policy (CAP Strategic Plans) and financed by the European Agricultural Guarantee Fund (EAGF) and by the European Agricultural Fund for Rural Development (EAFRD) and repealing Regulation (EU) No. 1305/2013 of the European Parliament and of the Council and Regulation (EU) No. 1307/2013 of the European Parliament and of the Council. COM/2018/392 final.

GUS (2013). Rolnictwo na obszarach specyficznych. Powszechny Spis Rolny 2010. Warszawa: GUS.

GUS (2017). Charakterystyka gospodarstw rolnych w $2016 r$. Warszawa: GUS.

OECD data. Retrieved from: https://stats.oecd.org/index.aspx?queryid=77269.

Matyka, M., Jugowar, J.L., Kowalczyk, A., Kozyra, J., Łopatka, A., Piórkowski, H., Radzikowski, P., Siebielec, G. (2019). Ocena rezultatów wdrażania Programu Rozwoju Obszarów Wiejskich na lata 2014-2020 w latach 2014-2018. Zadanie II - środowisko i klimat. Raport sporządzony dla MRiRW, Puławy.

Zieliński, M., Sobierajewska, J., Kagan, A. (2017). Aktualizacja metody wyznaczania gospodarstw $i$ obszarów o ekstensywnej produkcji rolnej w ramach HNV wraz z obszarami charakterystycznymi dla HNV (wariant II). Expert opinion by IERiGŻ-PIB for the MRiRW. Warszawa. 


\title{
GOSPODARSTWA ROLNE Z OBSZARÓW O SZCZEGÓLNIE DUŻEJ WARTOŚCI PRZYRODNICZEJ (HNV) NA TLE GOSPODARSTW POZOSTAŁYCH
}

\begin{abstract}
Abstrakt
W opracowaniu dokonano analizy porównawczej obszarów (gmin) o różnym nasyceniu użtkami rolnymi High Nature Value (UR HNV) oraz oceny funkcjonowania gospodarstw rolnych z tych obszarów w Polsce. W pierwszej kolejności wydzielono trzy grupy gmin różniacych się udziałem UR HNV w powierzchni ogółem. Pierwsza grupę stanowity gminy o udziale UR HNVw powierzchni ogółem wynoszacym poniżej 10\% (gminy I), druga gminy o udziale UR HNV równym bądź większym od 10 i mniejszym od 40\%, a trzecia gminy o udziale UR HNV co najmniej 40\% (gminy III). W gminach tych ocenie poddano przeciętna liczbe gospodarstw rolnych wraz z ich przeciętna powierzchnia UR, udziat procentowy (\%) gmin z gospodarstwami rolnymi o przeciętnej powierzchni UR równej bądź większej od średniej dla Polski, a także zmianę \% liczby ludności i udziat \% gmin o spadku liczby ludności o co najmniej 5\% w latach 2004-2017 oraz ich przeciętny wskaźnik waloryzacji rolniczej przestrzeni produkcyjnej (WRPP). W następnej kolejności ocenie funkcjonowania poddano 2878 gospodarstw z produkcja roślinna, zwierzęca $i$ wielostronna (roślinno-zwierzęca) z tych gmin, które prowadzity nieprzerwanie rachunkowość dla Polskiego FADN w latach 2014-2016. W ocenie tej wzięto pod uwage ich potencjat produkcyjny, organizacje produkcji, produktywność ziemi i pracy oraz dochód $w$ przeliczeniu na 1 FWU. W opracowaniu wykorzystano dane Agencji Restrukturyzacji i Modernizacji Rolnictwa (ARiMR), Instytutu Uprawy Nawożenia i Gleboznawstwa - PIB (IUNG-PIB), dane z gospodarstw rolnych prowadzacych rachunkowość dla Polskiego FADN w latach 2014-2016, a także dane literaturowe.
\end{abstract}

Słowa kluczowe: użytki rolne High Nature Value (UR HNV), krajobraz, bioróżnorodność, gospodarstwo rolne, dochód na 1 FWU.

Accepted for print: 13.03.2020.

Unless stated otherwise all the materials on the website are available under the Creative Commons Attribution 4.0 International license.

Some rights reserved to the Institute of Agricultural and Food Economics - National Research Institute.

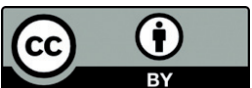

